\title{
INNOVATIVE POTENTIAL IN THE CONTEXT OF DETERMINING THE INNOVATIVE ACTIVITIES RESULTS OF INDUSTRIAL ENTERPRISES
}

\section{Oleksandra Nosovets ${ }^{1}$ \\ Lidiia Voloshchuk ${ }^{2}$}

DOI: https://doi.org/10.30525/978-9934-588-15-0-39

\begin{abstract}
The article deals with the state of the study of the essential characteristics determining problem, differentiation, criterion classification of the innovation activity results as the goals of its implementation and assessment markers of pragmatism involvement in innovation activity by individual subjects of the economy. For the purposes of the study, a low study level of the innovative activity results in the scientific literature interpretation in business and Ukrainian law-making practices and limited in the form of reducing their varieties to an innovative product as an intellectual law object and innovative products. Given the importance of influencing the innovation results formation in such specific economic categories of innovative science as innovation potential, innovation activity, innovation process, innovation infrastructure, innovation system and others, in this scientific research attention is paid to the feather. In order to find out the innovative potential essence in the context of its historical isolation into a separate category of economic potential and place of this type enterprise potential in the results formation of commercialization of scientific developments and utility models, marketing and management decisions, the morphological analysis of definitions of existing scientific terminology of the study potential was carried out. What is the purpose of analyzing and systematizing scientific approaches to determine the innovative potential essence, subsequently used to build understanding of its categorical apparatus and to compare the economic and innovation potentials concepts with the deduction of meaningful ordering structural elements markers and its relationship with the potential itself concept enabling to trace the primary

\footnotetext{
${ }^{1}$ Postgraduate Student of the Department of Accounting, Analysis and Audit, Odessa National Polytechnic University, Ukraine

${ }^{2}$ Doctor of Economics, Associate Professor,

Head of the Department of Accounting, Analysis and Audit,

Odessa National Polytechnic University, Ukraine
} 
concept detail with the innovative science development. As a result of morphological potential varieties analysis, based on the above classification of approaches to their essential disclosure, a scheme of their comparative systematization in the context of determining the innovative activity results was constructed. During the research, the author's innovative potential interpretation was deduced, taking into account the shortcomings of different approaches and definitions based on their principles. Owing to the conducting research of existing interpretations of economic and innovation potentials of entrepreneurial structures to identify in their composition, obtained in the process of economic and innovation activities implementation, keywords that are the resultant elements, innovative potential interpretation variants were deduced as an innovation activity result in confirming the cyclicality of innovation process and the innovation lifecycle, resulting in the author's innovation potential definition being formed as a innovation activity result. Innovative potential consideration is justified as a factor influencing the effectiveness of conducting the analyzed activity and the results emergence from the introduction of innovation in accordance with the interpretation of it as a set of factors by scientists. In the course of the research, it is stated on the basis of reciprocity validity confirmation of innovative potential and innovative activity influence, in particular in the part of human capital as the main creator of created values, on carrying out of innovative activity a place of innovative potential in formation and development of intellectual and innovative capital of the enterprise and in connection with them a attributing it to the resulting qualitative characteristics. Also, innovation potential is defined as the result of various factors acting on the field of activity of the production and economic system. The leading place of innovative potential in the formation of intellectual and innovative capital has been determined, making it the resultant qualitative characteristic of the economic entity and stipulating the inverse recurring and inherited interconnection potential and varieties of capital.

\section{Introduction}

The scientific and technological progress (STP) development with its transformative world picture turbulence, especially large-scale technological transformations, is accompanied by waves of unemployment and changes in the employment structure and specialists redistribution by professional direction, economic activity, generating unpredictable changes in 
purchasing potential consumers power of manufactured products. The STP is also marked by ruthlessness to the labor quality as to the most valuable of the enterprise resources, characterized by being outside its property and within its control and acting in accordance with the marketing approach to the intellectual capital classification as the value creator of its goods, works, services and taking an unconditional part creating strategic competitive advantage for the entity and its market value.

Market fluctuations keep businesses in the uninterrupted stress station and make forced to constantly keep «abreast» due to the transfer and implementation of technology and other innovations resulting achievement, preservation, approval of any development kind sustainability, especially based on innovations with a high risk degree of its commercialization under a factors variability, is a manifestation of the high management professionalism of economic entities and a display of high human resources quality. In particular, the personnel influence importance in the innovation potential structure on the efficiency performance of both economic and research activities is explained by the relationship with innovation activity and its base on the staff activity according to research by some scientists.

As innovation potential is based on the existing relevant innovative development way of resource provision of different economy level of entrepreneurial and other target activity subjects, it is responsible for their readiness for innovative transformation of goal setting and activity and their ability to occupy the set «peaks» and, as a consequence, precedes the immediate innovation process with the control measures importance determining for its creation, using, preservation, updating and enhancement in order to increase the effectiveness and to reduce the maneuvering risk in the conditions of the economic environment turbulence and the resultant return obtaining from the R\&D achievements implementation.

Formulation of the problem. Determination of the essential characteristics, differentiation, criterion classification of the innovation activity results as the goals of its implementation and assessment markers of pragmatism involvement in innovation activity by individual economic entities remains a cross-cutting stone of modern research due to the low study level in scientific literature and limited interpretation in practice and the legislative level of the matter that is reduced to an innovative product as an intellectual law object and innovative products. 
It is important to determine the impact on the innovation results formation by specific economic categories of innovation science, such as innovation potential, innovation activity, innovation process, innovation infrastructure, innovation system, etc.

Analysis of recent research and publications. Considerable contribution to the research and solving of innovative potential of enterprises has been made by such domestic and foreign scientists as: O.B. Aref'eva, V.A. Verba, M.P. Voinarenko, A.E. Voronkova, A.P. Grechan, A.V. Grinev, S.I. Gritsulenko, O.A. Girenko-Kotsuba, P.M. Zavlin, S.M. Ilyashenko, V.O. Kalishenko, N.V.Kasyanov, O.V.Korenkov, O.V. Kosolapov, N.V. Krasnokutskaya, E.V. Lapin, E.P. Mazur, L.S. Martyusheva, O.I. Mytyakova, I.V. Novikova, O.I. Oleksiuk, V.M. Orlov, G.A. Otlyvanska, I.V. Rodionova, I.M. Repin, R.R. Rusin-Grinik, G.O. Smirnova, Ya.V. Smirnov, V.P. Solovyov, M.M. Titova, I.I. Umansky, O.V. Farat, R.A. Fatkhutdinov, V.G. Fedorenko, O.S. Fedonin, L.I. Fedulova, E.S. Chermoshenko, N.I. Chukhray, O.Yu. Shilova, Yu.S. Shipulin and many others [1].

The work of scientists is devoted to the innovative potential essence and structure investigation, factors identification that influence it, methodological approaches development to its evaluation, such as: A.I. Akmayev, L.O. Voloshchuk, E.S. Galushka, V.N. Gunina, S.M. Ilyashenko, M.O. Kravchenko, N.V. Krasnokutskaya, I.O. Kuznetsova, A.A. Kuteinikova, N.I. Lapina, A.E. Luzina, I.V. Novikova, N.S. Popovenko, O.V. Posilkina, A.I. Prigogine, O.I. Prodius, O.S. Fedonina, S.V. Filippova, N.I. Chukhray and others. In particular, a significant contribution to the grounding development of place, value and transformation in connection with other structural elements of the intellectual component of the enterprise capital system and its potential was made by scientists: A.B. Butnik-Siversky, G.M. Dobrov, M.P. Ivanov, S.N. Klimov, K.V. Kovtunenko, V.M. Korobka, T. Sakaya [2-8].

Research of innovative theory problems, in particular the «innovative potential» concept definition is reflected in the scientific works of domestic and foreign scientists: I. Balabanova, Yu.O. Baklanova, S. Vovkanicha, L.O. Voloshchuk, G. Goldstein, V. Gromeka, M. Danko, M. Dolishny, V.I. Zakharchenko V. Kalyshenko, L. Kolosov, O. Kuzmina, L. Martyusheva, A. Nikolaev, E. Penrose, M. Porter, A. Perlaki, A. Prigozhina, A. Savchenko, A. Savchuk, V. Semynozhenko, A.M. Sergeev, S.A. Trukhin, K. Freeman [9-16] and others. However, there is still no 
consensus in the views of contemporary authors on the «innovation potential» concept interpretation.

The issues of comparing and satisfying the interests of internal and external economic impact groups in assessing the goals and economic enterprise indicators of measuring the completeness and effectiveness of their achievement in order to increase investment attractiveness, starting from the economic potential alignment and the innovative potential emergence, were given attention in her works. S.V. Filyppova [17].

As the innovation activity result and the factor influencing its receipt, the innovation potential was not considered, and the issues mentioned above for the purposes of this study are important for solving the tasks set out in it.

Highlighting previously unresolved parts of a common problem. Given the importance of a clear object definition to be controlled and subjectivity of influence on it, the systematization of established and new innovation potential definitions with their correlation requires conducting and serves as the main task of this study along with the impact survey of the innovation science concept in the innovative activity results formation and with the determining its place in responding to the existing resources using on the path to innovative development.

The purpose of this research is to find out the essence of innovative potential in the context of its historical allocation into a separate category of economic potential and the context of the topic of participation of innovative direction potential in shaping the results of realization of this development direction.

The very emergence and widespread use of the concepts of «innovation activity» and «innovation potential» became a conceptual reflection of the innovation activity phenomenon, which has become increasingly important in the activities of leading companies in the world economy [9].

Innovative potential and innovative activity are the cause and effect linkage components of the innovation activity results formation, defining them as objects of control in the implementation of an effective innovation process, exhaustive in terms of efficiency and rich in manifestations of its diversity. Innovative potential as a contributing factor and a providing innovative transformation processes factor in the enterprise is at the innovation process beginning and serves as a starting point for changing the status of innovation (inertia, potentiality, activity). This determines the need to take into account the impact of the subsequent corresponding changes of the first-line shifts on the order and stage 
of the criterion of compliance with the timeliness, holding time. This means that innovation-oriented potential requires close control by the management apparatus employees for compliance with the set goals, capacity building, their achievement and preservation with increase and improvement, and provided the plan of achievement of the set characteristics is achieved by the expected results, based on their available capabilities and the need to correct them. And any control begins with defining the object-scope of the control actions.

\section{Morphological analysis of the terminological research base}

Despite the fact that the terms «innovation activity» and «innovation potential» have become widespread in the domestic and foreign economic literature, their unambiguous definition has not yet been elaborated, which complicates the development of measures for the purposeful development and implementation of these concepts. In most scientific works, textbooks and practical developments on the issues of innovative activity of business entities and innovation management, the essential and specific characteristics of the studied categories are not given [9].

First of all, to the essential disclosure submitting of the investigated innovative category, we will analyze and submit it in the form of a table. 1 in a systematic form the identifying approaches results to determine the innovation potential with the subsequent practical application of their cited classification.

Comparison of innovative and economic potentials based on the above approaches to essential disclosure (Table 2, Table 3) will allow to understand more deeply the content of the studied category and to trace the detailing of the primary concept in the innovative science development process.

The above scientific approaches explore only certain aspects of the innovation potential, without fully revealing the essence of this concept. This is due to some extent to the objective factor, the scope and nature of the research goals. Therefore, the definition of innovation potential should be approached as an economic category, which is a hierarchically organized system of concepts that are at different levels of expression: from primary categories to those that logically follow one another, that is, subordinated and coordinated with each other. This characterizes the multilevel essence of innovation potential, the disclosure of which requires the use of an integrated approach. It is an integral approach that allows you to take advantage of all approaches to the definition of innovative potential and to reveal the dialectic of its formation and development [34]. 


\section{Systematization of scientific approaches to the definition of the «innovative potential» category}

\begin{tabular}{|c|c|c|}
\hline Approach & Essence & Disadvantages \\
\hline 1 & 2 & 3 \\
\hline $\begin{array}{l}\text { Scientific } \\
\text { and technical } \\
\text { approach } \\
\text { (determinism) }\end{array}$ & $\begin{array}{l}\text { Identification of the } \\
\text { concepts «innovation } \\
\text { potential» and «scientific } \\
\text { and technical potential» }\end{array}$ & $\begin{array}{l}\text { This approach leaves beyond the } \\
\text { consideration of at least two aspects } \\
\text { of the distinguishing problem the } \\
\text { essential and specific features of the } \\
\text { «innovation potential» concept: } \\
\text { 1. Not all market innovations } \\
\text { are strictly related to scientific } \\
\text { developments. } \\
\text { 2. The lack of appropriate management } \\
\text { and marketing mechanisms leads to the } \\
\text { fact that many scientific developments } \\
\text { are not implemented in the form of } \\
\text { marketable goods and services. }\end{array}$ \\
\hline $\begin{array}{l}\text { Resource } \\
\text { approach } \\
\text { (determinism) }\end{array}$ & $\begin{array}{l}\text { The resource approach } \\
\text { determines the innovation } \\
\text { potential through } \\
\text { consideration of a set of } \\
\text { resources necessary and } \\
\text { sufficient, according to the } \\
\text { authors, for the enterprise to } \\
\text { realize innovative activity. }\end{array}$ & $\begin{array}{l}\text { If the approach is taken as a guide to } \\
\text { action, then the management of the } \\
\text { company begins to increase the resource } \\
\text { base (or refers to the lack of innovation } \\
\text { activity due to the lack of appropriate } \\
\text { resource base), which does not directly } \\
\text { lead to an increase in innovation activity } \\
\text { of the organization. As a result, having } \\
\text { a huge set of resources, the company } \\
\text { cannot gain growth in new, innovative } \\
\text { and competitive goods and services in } \\
\text { the market. }\end{array}$ \\
\hline $\begin{array}{l}\text { Func-tional } \\
\text { (factor) } \\
\text { approach }\end{array}$ & $\begin{array}{l}\text { The factor approach represents } \\
\text { potential as a system of } \\
\text { material and labor factors } \\
\text { (conditions, constituents) that } \\
\text { ensure the achievement of the } \\
\text { purpose of production. The } \\
\text { basis for this approach is K. } \\
\text { Marx's statement that labor, } \\
\text { labor, and labor as factors of } \\
\text { production and elements of } \\
\text { value creation all appear to be } \\
\text { opportunities that emphasize } \\
\text { their potential nature. To turn } \\
\text { this possibility into a reality, } \\
\text { «they need to connect». }\end{array}$ & $\begin{array}{l}\text { This approach also does not fully } \\
\text { reveal the potential of the definition, } \\
\text { since it focuses on simply identifying } \\
\text { alternatives to using an existing } \\
\text { resource or finding vectors for its } \\
\text { accumulation. }\end{array}$ \\
\hline
\end{tabular}


End of Table 1

\begin{tabular}{|c|c|c|}
\hline 1 & 2 & 3 \\
\hline $\begin{array}{l}\text { Potential } \\
\text { approach (by } \\
\text { readiness) }\end{array}$ & $\begin{array}{l}\text { Defines the «innovation } \\
\text { potential» concept through } \\
\text { the term «readiness». Takes } \\
\text { into account the sufficiency } \\
\text { of the achieved level of } \\
\text { potential for innovation } \\
\text { activity of the economy. }\end{array}$ & $\begin{array}{l}\text { The definition of «readiness» implies } \\
\text { the presence of an external impetus, an } \\
\text { external team, which the company is } \\
\text { ready (or not ready) to fulfill. Modern } \\
\text { business requires the creation of a new, } \\
\text { not reactive, but proactive behavior, } \\
\text { which is the ability to act, not by } \\
\text { the will of circumstances, but by } \\
\text { anticipating them, not adapting to the } \\
\text { market, but shaping it. }\end{array}$ \\
\hline $\begin{array}{l}\text { Producti-ve } \\
\text { approach (by } \\
\text { possible) }\end{array}$ & $\begin{array}{l}\text { Defines the «innovation } \\
\text { potential» concept through } \\
\text { the term «opportunity» } \\
\text { (ability). Takes into account } \\
\text { the ability of the enterprise } \\
\text { to carry out innovative } \\
\text { activities. } \\
\end{array}$ & $\begin{array}{l}\text { Such definitions, correctly grasping the } \\
\text { connection of the «potential» concept } \\
\text { with the «ability» concept, do not } \\
\text { explain what the specific features of } \\
\text { such abilities. }\end{array}$ \\
\hline $\begin{array}{l}\text { System } \\
\text { approach }\end{array}$ & $\begin{array}{l}\text { Considers potential as } \\
\text { the ability of a resources } \\
\text { complex of an economic } \\
\text { system (subsystem) to fulfill } \\
\text { its tasks. Potential, in their } \\
\text { view, is a holistic view of } \\
\text { the structure and function } \\
\text { unity of the object, revealing } \\
\text { their relationship. On this } \\
\text { basis, it is concluded that } \\
\text { the collective capacity of } \\
\text { the team (other resource) } \\
\text { to perform certain tasks - } \\
\text { the more successfully the } \\
\text { structure of the object, the } \\
\text { more consistent its structural } \\
\text { and functional elements, } \\
\text { the higher its potential and } \\
\text { efficiency. }\end{array}$ & $\begin{array}{l}\text { Simplified understanding of the } \\
\text { enterprise potential, since the } \\
\text { production resource or factor ability } \\
\text { to obtain the desired result is without } \\
\text { the implementation of the managerial } \\
\text { component as only a possible and } \\
\text { static value because management is } \\
\text { not an auxiliary or related process of } \\
\text { realizing the enterprise potential, but } \\
\text { its direct motivation and source of } \\
\text { rational use. }\end{array}$ \\
\hline $\begin{array}{l}\text { Integrated } \\
\text { approach }\end{array}$ & $\begin{array}{l}\text { Giving a versatile character } \\
\text { to the concept. Taking into } \\
\text { account the versatility of } \\
\text { innovation potential. }\end{array}$ & $\begin{array}{l}\text { The complexity of the definitions. } \\
\text { Consideration of individual aspects } \\
\text { of innovation potential and leveling } \\
\text { others. }\end{array}$ \\
\hline
\end{tabular}

Source: systematized by the authors on the basis of sources [2; 9] 
Definition of the category «economic potential» according to various scientific sources

\begin{tabular}{|c|c|}
\hline Source & Definition \\
\hline 1 & 2 \\
\hline \multicolumn{2}{|r|}{ Macroeconomic approach } \\
\hline \multicolumn{2}{|r|}{ Object-subject approach } \\
\hline \multicolumn{2}{|r|}{ Resource approach } \\
\hline O.F. Balatsky & $\begin{array}{l}\text { Economic potential is the aggregate ability of available } \\
\text { economic resources to produce the maximum amount of utility } \\
\text { that meets the needs of society at some stage of its development. }\end{array}$ \\
\hline \multicolumn{2}{|r|}{ Microeconomic approach } \\
\hline \multicolumn{2}{|r|}{ Object-subject approach } \\
\hline \multicolumn{2}{|r|}{ Resource approach } \\
\hline $\begin{array}{l}\text { T.V. Kalinescu, } \\
\text { Yu.A. Romanovskaya, } \\
\text { O.D. Kirilov }\end{array}$ & $\begin{array}{l}\text { Enterprise potential is a set of resources, organized in certain } \\
\text { socio-economic forms, which, under certain existing internal } \\
\text { and external environmental factors, can be directed to the } \\
\text { realization of the activity of the enterprise, the purpose of } \\
\text { which is to meet the new needs of society. }\end{array}$ \\
\hline V.V. Rossosh & $\begin{array}{l}\text { The potential of an enterprise is a set of resources and } \\
\text { opportunities available to an economic entity that can be used } \\
\text { to achieve this goal. }\end{array}$ \\
\hline \multicolumn{2}{|r|}{ Productive approach (by possible (ability)) } \\
\hline $\begin{array}{l}\text { Yu.I. Grishova, } \\
\text { I.S. Dolzhsky, } \\
\text { I.O. Kryukov }\end{array}$ & $\begin{array}{l}\text { The economic potential of an enterprise is the ability of its } \\
\text { resources, namely internal capabilities and key competencies, } \\
\text { to ensure the realization of strategic priority interests, which } \\
\text { defines it as a coherent system, which includes the factors of } \\
\text { strategic development of the enterprise. }\end{array}$ \\
\hline \multicolumn{2}{|r|}{ System approach } \\
\hline \multicolumn{2}{|r|}{ Functional (factor) approach } \\
\hline $\begin{array}{l}\text { O.V. Berezin, } \\
\text { K.A. Mammon }\end{array}$ & $\begin{array}{l}\text { Economic potential is a set of organizational, production, } \\
\text { material, financial and labor factors and is considered as } \\
\text { the result of production and economic relations that arise } \\
\text { between economic entities. }\end{array}$ \\
\hline \multicolumn{2}{|r|}{ System approach } \\
\hline $\begin{array}{l}\text { Conceptual Glossary } \\
\text { «Economics: A to Z» }\end{array}$ & $\begin{array}{l}\text { Economic potential is defined as the ability of the economy } \\
\text { of the country, its industries, enterprises, economies to carry } \\
\text { out production activities, produce products, goods, provide } \\
\text { services, meet the demand of the population, social needs, to } \\
\text { ensure the development of production and consumption. }\end{array}$ \\
\hline
\end{tabular}


End of Table 2

\begin{tabular}{|l|l|}
\hline \multicolumn{1}{|c|}{$\mathbf{1}$} & \multicolumn{1}{c|}{$\mathbf{2}$} \\
\hline $\begin{array}{l}\text { B.L. Kuznetsov, } \\
\text { A.V. Kutsenko, } \\
\text { I.P. Here }\end{array}$ & $\begin{array}{l}\text { The potential of the enterprise is a systematic set of means of } \\
\text { work, objects of work, employees, taking into account their } \\
\text { intellectual and moral and ethical qualities, work experience, } \\
\text { motives, incentives and traditions formed in the team. }\end{array}$ \\
\hline \multicolumn{1}{|c|}{ Integrated approach } \\
\hline & $\begin{array}{l}\text { Comprehensive (integral) approach } \\
\text { M.V. Savchenko }\end{array}$ \\
$\begin{array}{l}\text { Economic potential is a complex economic system of } \\
\text { functional relations between elements of the real and } \\
\text { potential levels of enterprise development, which reflects its } \\
\text { willingness at some time to mobilize resources to achieve } \\
\text { its goals with maximum efficiency in the process of optimal } \\
\text { interaction with the external environment. }\end{array}$ \\
$\begin{array}{l}\text { O.S. Fedonin, } \\
\text { I.M. Repin, } \\
\text { O.I. Oleksiuk }\end{array}$ & $\begin{array}{l}\text { The potential of the enterprise is an integral reflection } \\
\text { (evaluation) of current and future opportunities of the } \\
\text { economic system to transform the input resources with the } \\
\text { help of the inherent entrepreneurial abilities of the personnel } \\
\text { into economic benefits, thus satisfying corporate and public } \\
\text { interests as much as possible. }\end{array}$ \\
\hline
\end{tabular}

Source: compiled by the authors on the basis of sources systematization [18-31]

Table 3

\section{Definition of the category «innovation potential» by different regulatory and scientific sources}

\begin{tabular}{|l|l|}
\hline \multicolumn{1}{|c|}{ Source } & \multicolumn{1}{c|}{ Definition } \\
\hline \multicolumn{1}{|c|}{$\mathbf{1}$} & \multicolumn{1}{c|}{ Macroeconomic approach } \\
\hline \multicolumn{1}{|c|}{ Object-subject approach } \\
\hline & \multicolumn{1}{c|}{ Scientific and technical approach } \\
\hline $\begin{array}{l}\text { B.A. Reisberg, } \\
\text { L.Sh. Lozovsky, } \\
\text { E.B. Starodubtseva }\end{array}$ & $\begin{array}{l}\text { Innovative potential is the scientific and technical potential } \\
\text { of the country in the form of research, design, technological } \\
\text { organizations, experimental productions, experimental landfills, } \\
\text { educational institutions, personnel and technical means of these } \\
\text { organizations. }\end{array}$ \\
\hline \multicolumn{1}{|l}{$\begin{array}{l}\text { Priority directions } \\
\text { of innovative } \\
\text { activity in Ukraine }\end{array}$} & $\begin{array}{l}\text { Innovative potential is a set of scientific, technological, financial } \\
\text { and economic, production, social and cultural and educational } \\
\text { opportunities of the country (industry, region, enterprises, etc.) } \\
\text { necessary to ensure the innovative development of the economy. }\end{array}$ \\
\hline
\end{tabular}


Continuation of Table 3

\begin{tabular}{|c|c|}
\hline 1 & 2 \\
\hline \multicolumn{2}{|r|}{ Mesoeconomic approach } \\
\hline \multicolumn{2}{|r|}{ Object-subject approach } \\
\hline \multicolumn{2}{|r|}{ Resource approach } \\
\hline L.A. Benovskaya & $\begin{array}{l}\text { The region's innovation potential is a combination of conditions } \\
\text { and a set of human, research, logistical, financial, and } \\
\text { information resources, which are closely interconnected, used to } \\
\text { innovate the subjects of the region, and thus provide the region } \\
\text { with competitive advantages. }\end{array}$ \\
\hline \multicolumn{2}{|r|}{ Productive approach (by possible (ability)) } \\
\hline S.A. Truchin & $\begin{array}{l}\text { The innovative potential of a region is a set of scientific, } \\
\text { technological, industrial, technological, personnel, } \\
\text { infrastructure, financial, legal and other opportunities of } \\
\text { economic entities of the region to promote and diffuse } \\
\text { innovation. }\end{array}$ \\
\hline \multicolumn{2}{|r|}{ Integrated approach } \\
\hline \multicolumn{2}{|r|}{ Comprehensive (integral) approach } \\
\hline O.Y. Baklanova & $\begin{array}{l}\text { The innovation potential of the region is the sources, } \\
\text { opportunities, means of creation to optimize the contribution } \\
\text { of science and technology to economic development through } \\
\text { the implementation of market principles in this field and its } \\
\text { restructuring. }\end{array}$ \\
\hline \multicolumn{2}{|r|}{ Microeconomic approach } \\
\hline \multicolumn{2}{|r|}{ Object-subject approach } \\
\hline \multicolumn{2}{|r|}{ Scientific and technical approach } \\
\hline M. Danko & $\begin{array}{l}\text { Innovative potential is the accumulated amount of information } \\
\text { about the results of scientific and technical works, inventions, } \\
\text { design and development, samples of new machinery and products. }\end{array}$ \\
\hline \multicolumn{2}{|r|}{ Resource approach } \\
\hline $\begin{array}{l}\text { M.P. Voinarenko, } \\
\text { R.V. Skaluk }\end{array}$ & $\begin{array}{l}\text { Innovative potential is a certain critical mass of resources of } \\
\text { a business entity (intellectual, research, information, etc.), } \\
\text { necessary and sufficient for its optimal development on the basis } \\
\text { of constant search and use of new spheres and ways of realizing } \\
\text { market opportunities that open up to the market. It is related to } \\
\text { the modification of existing and the formation of new markets. }\end{array}$ \\
\hline $\begin{array}{l}\text { V.I. Zakharchenko, } \\
\text { N.M. Korsikova, } \\
\text { M.M. Merkulov }\end{array}$ & $\begin{array}{l}\text { Innovative potential is the set of resources directly involved in } \\
\text { the innovation process that are interrelated, and the factors that } \\
\text { create the necessary conditions for the effective use of these } \\
\text { resources in order to achieve appropriate innovation benchmarks } \\
\text { and increase the competitiveness of the enterprise as a whole. }\end{array}$ \\
\hline
\end{tabular}


End of Table 3

\begin{tabular}{|c|c|}
\hline 1 & 2 \\
\hline \multicolumn{2}{|r|}{ Potential approach (by readiness) } \\
\hline P.A. Fathutdinov & $\begin{array}{l}\text { The organizational potential of an organization is a measure } \\
\text { of the organization's willingness to fulfill the tasks that ensure } \\
\text { the achievement of the set innovation goal, that is, a measure } \\
\text { of readiness for the implementation of an innovative project } \\
\text { or program of innovation transformations and introduction of } \\
\text { innovations. }\end{array}$ \\
\hline \multicolumn{2}{|r|}{ Productive approach (by possible (ability)) } \\
\hline M.N. Titov & $\begin{array}{l}\text { Innovative potential is the ability of the real sector object under } \\
\text { consideration to provide a sufficient degree of renewal of } \\
\text { factors of production, their combinations in the process product } \\
\text { of the manufactured product, organizational and management } \\
\text { structures and corporate culture. }\end{array}$ \\
\hline \multicolumn{2}{|r|}{ System approach } \\
\hline \multicolumn{2}{|r|}{ Functional (factor) approach } \\
\hline I.V. Radivilo & $\begin{array}{l}\text { Innovative potential is a complex dynamic system } \\
\text { with simultaneous consideration and combination of } \\
\text { influence of environmental factors and factors, internal } \\
\text { and external opportunities and abilities, their effective use, } \\
\text { principles of timeliness and strategic orientation of the } \\
\text { enterprise. }\end{array}$ \\
\hline \multicolumn{2}{|r|}{ System approach } \\
\hline $\begin{array}{l}\text { O.P. Cavtish, } \\
\text { N.P. Pear }\end{array}$ & $\begin{array}{l}\text { The innovation potential of the enterprise consists of a managed } \\
\text { object and a set of interrelated management actions for planning, } \\
\text { forecasting, utilization, motivation and control of the whole } \\
\text { complex of resources and factors of production in the general } \\
\text { system of management of the enterprise, their directions and } \\
\text { sequence of application in order to ensure the execution set } \\
\text { before the enterprise. tasks, ensuring its further progressive } \\
\text { development. }\end{array}$ \\
\hline \multicolumn{2}{|r|}{ Integrated approach } \\
\hline \multicolumn{2}{|r|}{ Comprehensive (integral) approach } \\
\hline V. Vostryakova & $\begin{array}{l}\text { Innovative potential is an integral characteristic of a complex } \\
\text { of economic resources, current and future capabilities and } \\
\text { capabilities of the economic system to pursue targeted } \\
\text { innovation through the transformation of a set of resources, } \\
\text { taking into account the system of internal and external } \\
\text { factors. }\end{array}$ \\
\hline
\end{tabular}

Source: compiled by the authors on the basis of sources systematization [3-6; 10-15; 32; 33] 
Analyzing the theoretical basis of the content of the «innovative enterprise potential» concept, we can say that most authors are guided by the so-called resource approach, that is, define the innovative enterprise potential as a set of resources or a combination of them. Some definitions are based on a structural approach, often distinguishing such basic elements as research, personnel, information, logistical and financial components. Other scientists apply a process approach that takes into account the target innovation potential characteristic [35].

At the same time, the so-called innovation potential of the enterprise, which is a complex characteristic of the enterprise's ability to innovate, lies at the basis of all the identified phenomena (innovation development, innovation process, innovation activity) [36; 37].

Some researchers believe that the innovation potential components should include only those resources that can be used in the implementation of all stages of the goods lifecycle. Other scientists view innovation potential as the ability of an enterprise to develop and implement innovations in accordance with the required quality standards in order to adapt to changes in the external environment and allocate in its composition personnel, information, methodological, logistical and organizational-managerial components [2].

Related to the innovation potential concept is the innovation development potential concept. However, in the context of this study, these concepts are considered synonymous [38].

The systematic approach involves the use of the systematicity principle, that is, the study of innovation potential as a set of interconnected elements that function as a whole, under the environmental factors influence. Innovation potential, as shown above, has a number of its specific manifestations, which are interconnected within a specific production system, as well as the result and factor of other components of the enterprise's potential [39].

The innovative potential definitions presented by different scientists differ in the different coverage scope and processing degree of constituent elements of a complex system of a subject, regardless of its management level, which defines them as supporters of the relevant approaches based on the constituent elements, among which the most developed concept of the investigated potential in microeconomic management. Within the framework of the systematic approach, D.I. Kokurin traces the parallel interpretation of innovation potential with the identification of innovative enterprise 
activity with the innovative staff activity with the emphasis on business and personal qualities of management staff.

Summarizing these definitions of the «innovation potential» concept, we can note a significant scientific problem: none of them indicates that the innovative potential realization should ensure the intensive development of any enterprise, or any economic system, for which the definition is given of this concept. In this context, one cannot say that definitions are focused on the intensive development in the Law of Ukraine «On Priority Areas of Innovative Activity in Ukraine», which refers to «innovative» rather than intensive «economic development» [32]; provided by A.I. Akmayev and B.T. Kliyanenko, pointing to «sustainable development» [33]; by A.V. Dzubina, who focuses on «innovative development» [1] and MV Krasnokutskaya, which focuses on the overall «development of the organization» [40]: these types of development cannot be considered similar to intensive [41].

Not insignificant is the innovation culture, defined by the Law of Ukraine «On Priority Areas of Innovative Activity» as an innovative potential component, which characterizes the level of educational, general cultural and socio-psychological preparation of the individual and society as a whole for the perception and creative implementation of economic development ideas of the country on an innovative principles [32], whereby the innovation culture concept is broader than the innovation disposition concept as the next stage of development of society's response to innovation.

According to the results of the innovative and preceding economic potentials definitions analysis, their meaningful content construction will be submitted in the form of fig. 1-3 in comparison with the principle of multilevel classification of approaches.

In order to construct a schematic representation with the classification levels of the essential disclosure of the studied types of potentials, which were deduced in the course of the analysis, we will generically present the unity of meaningful markers of the different sources definition and compare them with economic and innovative potentials in the context of the historical separation of the last into a separate category.

As we can see, in terms of schemes and previously processed scientific materials, issues of the innovative potential content determination have received greater attention and deeper elaboration, manifested in more management levels. The conclusions will be clarified further by the phasing out of the research topics. 
According to A.M. Sergeyev [9], the innovation potential definition should enable to develop of management tools that allow to form and amplify this potential and seek to increase the innovation activity of the enterprise.

Based on these nuances and shortcomings of the existing interpretations, the authors have made their own contention about innovation potential

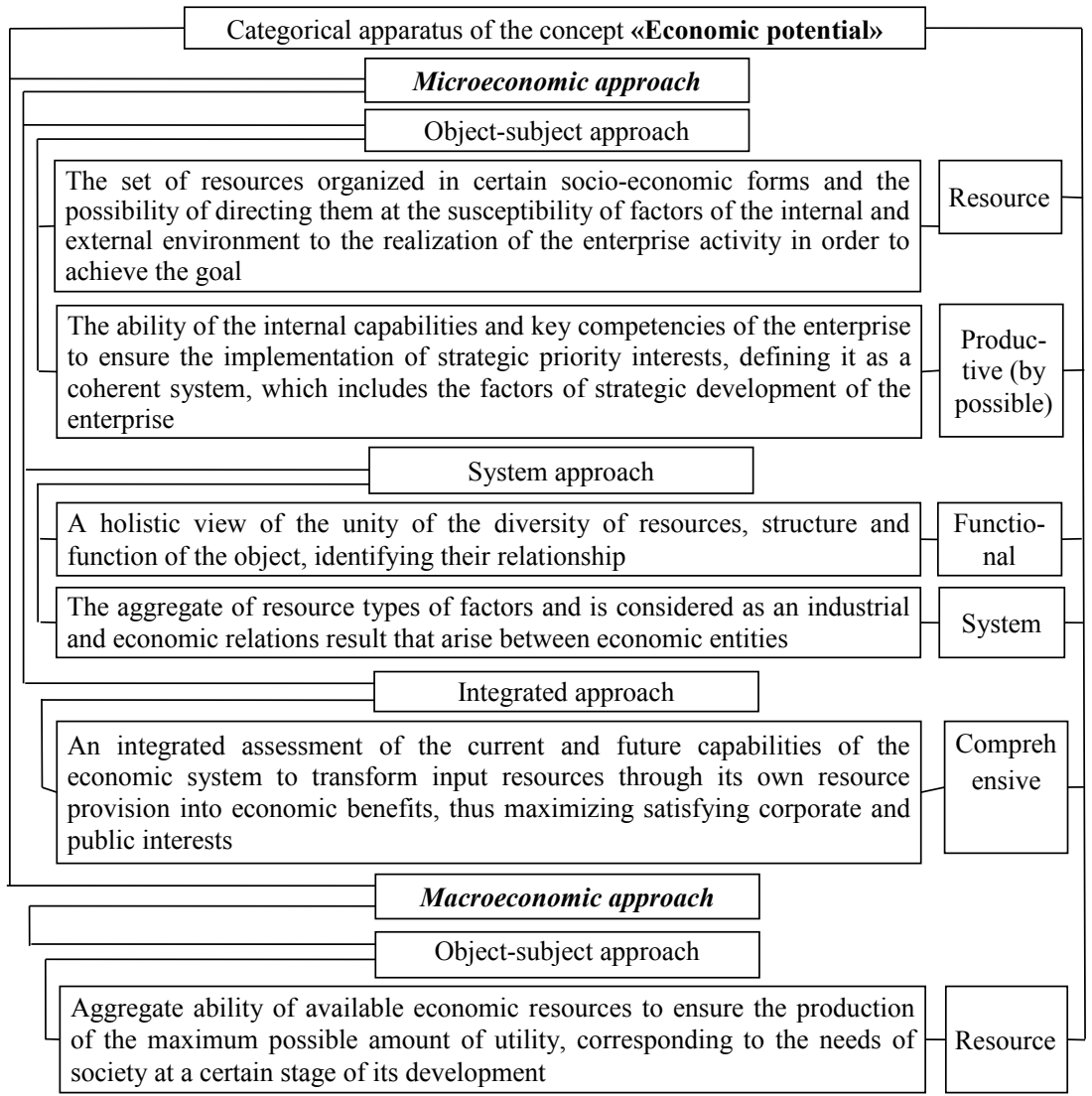

Figure 1. Categorical apparatus of the concept «economic potential» in context defining the innovation activity results in an approaches variability Source: compiled by the authors on the basis of sources systematization [3-6; 10-15; 18-31] 
Chapter «Economic sciences»

Categorical apparatus of the concept «Innovative potential»

\begin{tabular}{|l|}
\hline $\begin{array}{l}\text { Aggregate diversity of interconnected resources, necessary and sufficient in } \\
\text { the innovation process to constantly seek and effectively utilize opportunities } \\
\text { to modify internal and external factors to set the benchmarks for innovation } \\
\text { activity and increase the competitiveness of different types of entrepreneurial } \\
\text { results in order to achieve the strategic goals of the innovative orientation } \\
\text { enterprise }\end{array}$ \\
\hline
\end{tabular}

Combining innovative susceptibility by means of the resource types opportunities set and the innovativeness degree in the ability to create, effectively implement and disseminate $R \& D$ achievements, giving rise to a structural division of the entity into aggregates of diverse resources and their systematic renewal

Information base for R\&D achievements

A measure of the entity's readiness to accomplish the task of achieving the set innovation goals of the project or program of innovative strategic transformations and implementing the R\&D achievements

Resource

Productive (by possible)

System approach

A complex dynamic system of combining the influence of internal and external factors, opportunities, efficiency of their use in the innovation process in order to realize the principles of strategic orientation of the enterprise

Managed object and interrelated actions set for realization of management functions by dint of set of various interconnected resources and factors of realization of types of entrepreneurial activity in order to achieve strategic goals of the innovative orientation enterprise and to ensure its further progressive development

Integrated approach
$\begin{aligned} & \text { Integral efficient use characterization of resource provision and available } \\ & \text { enterprise capabilities to pursue targeted innovation activity under the } \\ & \text { internal and external factors influence through the R\&D achievements } \\ & \text { implementation in order to achieve the strategic goals of the innovative } \\ & \text { orientation enterprise }\end{aligned}$

Figure 2. Categorical apparatus of the concept «innovative potential» at the microeconomic level in context defining the innovation activity results in an approaches variability

Source: compiled by the authors on the basis of sources systematization [3-6; 10-15; 18-31] 
(as an innovative category), where it is a system of interrelated links between the entity's resources aggregate and its ability to engage resource provision aimed at forming an innovation culture within the organization and in society in order to encourage the innovative disposition making and, as a consequence, the achievement of the innovative nature tasks, achieving the strategic goals of innovation development subjects at different levels of management to its intensification.

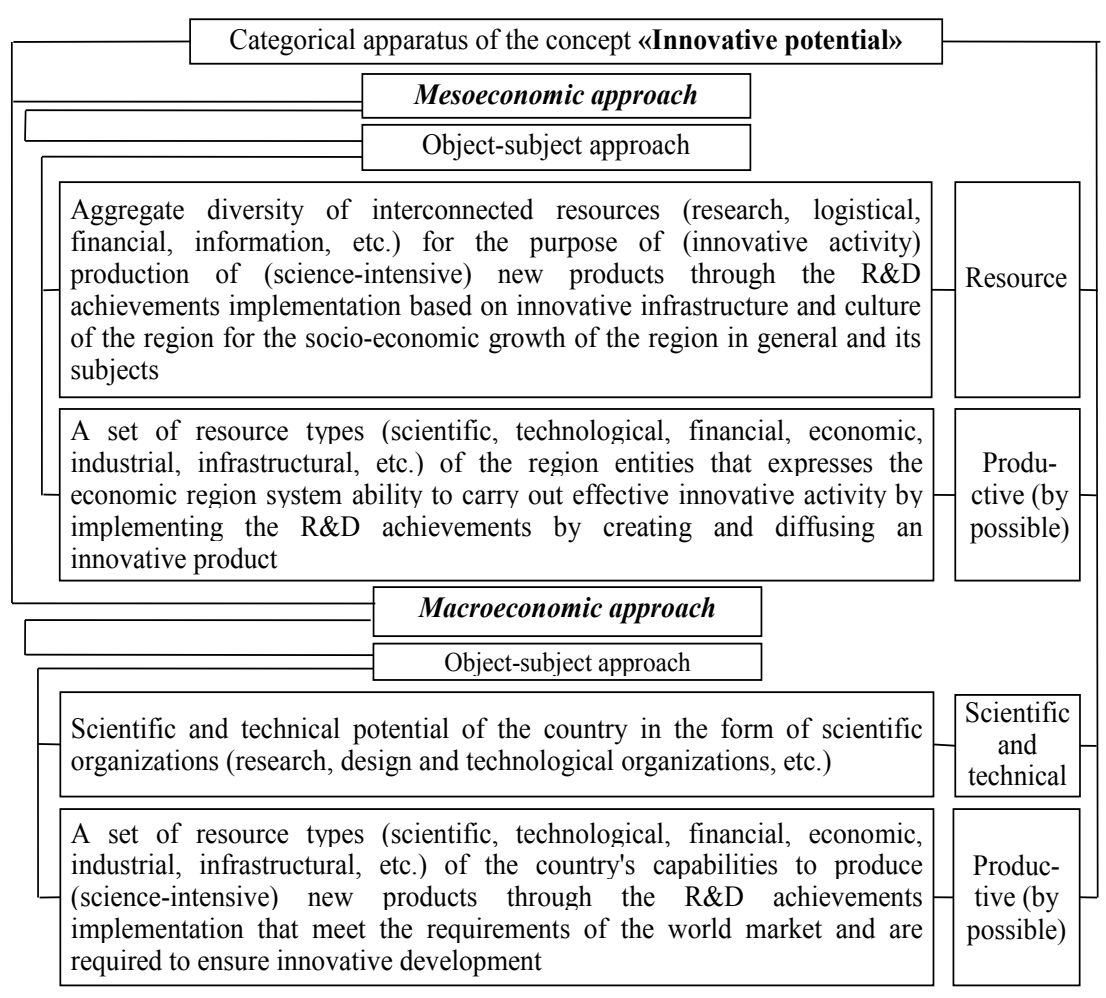

Figure 3. Categorical apparatus of the concept «innovative potential» at the mesoeconomic

and macroeconomic levels in context defining the innovation activity results in an approaches variability

Source: compiled by the authors on the basis of sources systematization [3-6; 10-15; 18-31] 


\section{Innovative potential in determining the innovation activities results}

Further research will be devoted to the theoretical substantiation of determining the innovative potential place in the composition of innovation activity results and its influence on their formation. The study of isolation of innovation from economic potential, often identified with the potential of the enterprise at the micro level leads to the formation of a logical conclusion: innovation potential differs from the economic potential component, the orientation to the development of fundamentally new goods and services, the introduction of fundamentally new technologies and elements of business processes. At the same time, approaches to the innovation potential definition inherit the nature and shortcomings of approaches to the definition of economic potential (resource approach), in particular at the macro and micro levels.

In turn, by determining the economic potential of O.V. Berezina and K.A. Mammonov is a set of organizational, production, material, financial and labor factors and is considered as the result of production and economic relations that arise between economic entities [24; 25], which implies the possibility of a mirror interpretation of innovation potential as a result of innovation activity, embedded in a systematic approach to the meaningful content of the studied economic category of the field of innovation. The conclusion about the innovative potential as the result and factor of other components of the enterprise potential by O.Yu. Shilova and E.S. Chermoshenko definition as one that is formed as a result of innovative changes in the principles, processes, organizations and structures of the enterprise, in confirmation of the innovation process cyclicality and the innovation lifecycle and in the proper management of assets and intangible values of ensuring the sustainability of innovative development.

Also, innovation potential may arise as a result of the factors influence of social and demographic enterprise environment, consumer purchasing power, and efficiency of innovative activity management.

In favor of the fundamental difference in the types of potentials under consideration, the following definition of O.S. Moroz [42]: innovation potential is a set of innovative susceptibility (to wit the ability of the production and economic system to introduce and use innovations of various kinds in their activities) and the enterprise innovativeness degree (an indi- 
cator that characterizes the possibility of transformation of scientific and technical development into novation, and then into innovation).

The innovation process involves many participants and has its own infrastructure. Market innovative infrastructure provides organizational, legal and economic support to the development of innovation potential of enterprises at different levels and in different forms [43]. Innovative potential in its essential resource diversity is the internal innovation infrastructure of the enterprise, both of which are the potential and infrastructure responsible for ensuring the activities implementation.

Guided by the scientists definition in explaining the innovative development concept, namely [44] is the development (as a result) on the basis of effective innovative activity implementation (for innovative enterprises), and development (as a process) on the basis of efficient innovative potential use (for any enterprises), - the hierarchical construction need of factors influencing the innovation activity becomes more important on the purpose of developing effective measures of leveling, counteraction and elimination [45]. Since innovation potential is a fundamental factor in pursuing activity based on the commercial mass embodiment of novation and, as a consequence, innovation development, it is appropriate to consider the innovation science category under study in terms of factorial ownership of innovation performance.

In addition to the result obtained in the first round of the stage of innovation and simultaneously inherited from the economic in accordance with the investigated terminological definition, innovation potential can be considered as a factor influencing the effectiveness of the analyzed activity and the emergence of results from the innovativeness introduction according to the interpretation of it as a set of factors by scientists V.I. Zakharchenko, N.M. Korsikova, I.V. Radzivilo and others. Innovation potential can also be viewed as a mirror to the factor definition of economic potential mentioned above, and therefore, as any factor of economic activity, being the aggregate factor of economic relations, is subject to and possible control by any interested parties and persons.

Being a generator of high innovation activity, innovation potential becomes the basis for the economic system to achieve higher level of development, increase creativity and readiness for innovative development [1].

In the course of introducing innovations on the basis of existing innovation potential, the formation and development of the intellectual and 
innovative capital of the enterprise takes place [46], contributing to the improvement of human capital qualification characteristics, which is the basic intellectual capital element and, as a consequence, the basic innovative capital element. Also on the innovation basis there is a creative thinking activation, improvement of conditions, work organization, in particular in the context of creating prerequisites for the innovation development, conducting innovative activity, thus its indirect influence once again causing the relationship with innovative activity - the activity of staff.

It should be noted that innovation potential is still one of the most complex and debatable categories in modern innovation theory. In the most widespread resource approach, it is viewed from a static point of view as a set of resources that reflect the existing resource provision of innovation activity and innovative development of the enterprise. However, some experts insist on considering innovation potential as an ability to innovate, which, in addition to resources, must also have the capacity to use them effectively.

However, this ability is conditioned by the staff competence, which is an integral part of the intellectual component of innovation potential [38], determining one of the leading places of innovation potential with reliance on the qualitative characteristics of labor resources in the formation of intellectual and innovative capital and, in turn, making it the resultant qualitative characteristic of the entity from the productivity and efficiency of their use in achieving them, stipulating the inverse recurring and inherited interconnection potential and varieties of capital. In confirmation of belonging to the resulting qualitative characteristics, and in the case of the innovative potential of the innovative activity characteristics, the interpretation of the innovative character potential as the ability, willingness to carry out innovative activity according to the potential and effective approaches to its determination, testifies.

Therefore, in view of the above, we can conclude in the form of definition of innovative potential (as a result), where it is the result of realization by the economic activity subject with the help of existing set of interconnected various resources used for transformation of economic, technological, business processes for innovative, its readiness to ensure the renewal degrees of factors of production and innovativeness by participating in the innovation diffusion and providing increased competitive advantages by making for acquiring the status of innovative and use for innovative 
enterprises of innovative susceptibility in the form of enhancement of each content-structural component of this innovation science category in order to carry out further innovative activity on the basis of the desire to intensify the knowledge-intensiveness incorporation into manufactured products and at a higher effective level of achievement of the tasks of effective innovative development.

\section{Conclusions and prospects for further research}

According to international experience, industry is considered to be the most productive of innovations. Manufacturing becomes more oriented not to the mass consumer, but to the specific needs of individuals, that is, to small markets. The number of entrepreneurial structures, especially small and medium-sized enterprises, that are able to adapt quickly to the requirements of the external environment is growing rapidly [43], testifying to the productivity and effectiveness of the innovative way of economic development in Ukraine and its individual entities.

According to the results of the research, many scientists were committed to the resource approach to the interpretation of innovation-oriented potential, whereby according to the source [11], the innovation potential represents a certain critical mass of resources of the business entity (intellectual, scientific, research and development, etc.) necessary and sufficient for its optimal development on the basis of constant search and use of new spheres and ways of realizing market opportunities that open to it, that is faced with the modification of the existing and the formation of new markets, identifying not the first time the innovative potential with the economic, to highlight the distinguishing features in which a comparative morphological analysis was performed.

Since, in general, the innovative feature of an enterprise's development from its development is its innovativeness [47], the innovative component of the innovation potential is its distinguishing feature from the economic potential as a category of economic science. Relying on theoretical gains in the definition of both types of potentials, one's own vision of interpreting innovative potential was deduced, taking into account the shortcomings of existing approaches to its definition and definitions.

On the basis of comparing the meaningful characteristics of the economic and innovation potentials concepts, the interpretation of the last as an innova- 
tion activity result and the influence factor on the activity implementation and receiving kickbacks have been deduced and substantiated by the constructing definition logic and common markers of the essence of both concepts. In addition to determining the innovation potential factoriality to assess the effectiveness of innovation activities and the results of its implementation in terms of obtaining the results from the commercialization of developments was established a leading place of the investigated category of innovation in the formation of intellectual and innovative capital, making it a resultant qualitative characteristic of the entity and stipulating the inverse recurrent and inherited interrelation of potential and varieties of capital.

The prospect of further research remains to deepen the study of innovation potential in its relation to and influence on the formation of innovation activity results, determining the effectiveness of innovation and, accordingly, the effectiveness of innovative development at all management levels.

\section{References:}

1. Dzjubina A.V. (2008). Rozkryttja zmistu ponjattja «innovacijnyj potencial» ta vyznachennja jogho skladovykh [Disclosure of the concept of «innovative potential» and definition of its components]. Nacionaljnyj universytet «Ljvivsjka Politekhnika» [Lviv Polytechnic National University] (electronic journal), pp. 72-77. Available at: http://ena.lp.edu.ua/bitstream/ntb/1981/1/12.pdf (accessed 08 September 2019).

2. Kavtysh O.P., Krush N.P. (2015). Teoretychno-metodychni pidkhody do vyznachennja sutnosti innovacijnogho potencialu pidpryjemstva [Theoretical and methodological approaches to determining the essence of the innovation potential of the enterprise]. Zhurnal Nacionaljnogho tekhnichnogho universytetu Ukrajiny «Kyjivsjkyj politekhnichnyj instytut» [Journal of the National Technical University of Ukraine «Kyiv Polytechnic Institute»] (electronic journal), no. 8, pp. 1-11. Available at: http://economy.kpi.ua/ru/node/315 (accessed 08 September 2019).

3. Rajzbergh B.A., Lozovskyj L.Sh., Starodubceva E.B. (2007). Sovremennij ekonomycheskyj slovarj [Modern economic dictionary]. Moscow: YNFRA-M. (in Russian)

4. Benovsjka L.Ja. (2010). Innovacijnyj potencial reghionu ta umovy jogho realizaciji [Innovative potential of the region and conditions for its realization] (electronic journal). Available at: http://www.nbuv.gov.ua/portal/soc_gum/ vldfa/2010_18/Benovska.pdf (accessed 11 September 2019).

5. Trukhyn S.A. (2006). Ocenka ynvestycyonnogho pryvlekateljnosty y yynovacyonnogho potencyala (na prymere Altajskogho kraja) [Assessment of investment attractiveness and innovative potential (on the example of Altai Krai)]. Polzunovskyj vesnyk [Polzunovsky Bulletin] (electronic journal), no. 3, pp. 200-203. Available at: http://elib.altstu.ru/elib/books/Files/pv2006_03_1/pdf/200truh.pdf (accessed 28 September 2019). 
6. Baklanova Ju.O. (2010). Ynnovacyonnыj potencyal reghyona y egho otkritostj po otnoshenyju $\mathrm{k}$ vneshnej srede [The innovative potential of the region and its openness in relation to the external environment]. Upravlenye ekonomycheskymy systemamy: elektronnij nauchnij zhurnal [Management of economic systems: an electronic scientific journal] (electronic journal), no. 1(12), pp. 1-13. Available at: http://uecs.mcnip.ru (accessed 28 September 2019).

7. Ivanov M.P. (2007). Chelovecheskyj kapytan y ghlobalyzacyja [Human Captain and Globalization]. Myrovaja ekonomyka y mezhdunarodnie otnoshenyja, no. 3 , p. 24.

8. Kovtunenko K.V (2013). Osnovni pidkhody do formuvannja intelektualjnogho kapitalu: zmist ta rolj $\mathrm{v}$ innovacijnomu rozvytku pidpryjemstva [The main approach to formulating the intellectual capital: the role in the innovative development of the enterprise]. Ekonomika pidpryjemstva ta upravlinnja vyrobnyctvom [Economy of management and control of the radio industry] (electronic journal), no. 3(67), pp. 59-62. Available at: http://nbuv.gov.ua/UJRN/ erco_2013_3_17 (accessed 17 September 2019).

9. Sergheev A.M. (2012). Ynnovacyonnaja aktyvnostj kompanyy [Company innovative activity]. Nauchno-praktycheskyj zhurnal «Myr» [Scientific and practical journal «World»] (electronic journal), no. june-september, pp. 47-51. Available at: https://cyberleninka.ru/article/v/innovatsionnaya-aktivnost-kompanii (accessed 17 September 2019).

10. Danjko M. (1999). Innovacijnyj potencial u promyslovosti Ukrajiny [Innovation Potential of Ukrainian Industry]. Ekonomist, no. 10, pp. 26-32.

11. Vojnarenko M.P., Skaliuk R.V. (2008). Innovacijnyj potencial promyslovykh pidpryjemstv: sutnistj, struktura, osoblyvosti ocinky ta perspektyvy rozvytku [Innovative potential of industrial enterprises: nature, structure, features of evaluation and prospects for development]. Visnyk Khmeljnycjkogho nacionaljnogho universytetu. Ekon. nauky, no. 1(2), pp. 7-12.

12. Zakharchenko V.I., Korsikova N.M., Merkulov M.M. (2012). Innovacijnyj menedzhment: teorija i praktyka $v$ umovakh transformaciji ekonomiky [navch. posib.] [Innovation management: theory and practice in the conditions of economic transformation [textbook tool]. Kiev: Centr navchaljnoji literatury. (in Ukrainian)

13. Fatkhutdynov R.A. (2003). Ynnovacyonnij menedzhment. Uchebnyk [Innovation Management. Textbook]. St. Petersburg: Pyter. (in Russian)

14. Smyrnova Gh.A., Tytova M.N., Mazur E.P. (2011). Ynnovacyonnij potencyal predpryjatyy, egho ocenka y metodi realyzacyy [The innovative potential of the enterprise, its assessment and implementation methods]. Pravo. Ekonomyka. Marketyngh, no. 7.

15. Radzivilo I.V. (2012). Mekhanizm formuvannja innovacijnogho potencialu promyslovogho pidpryjemstva: strukturyzacija ta identyfikacija elementiv [Mechanism of formation of innovative potential of industrial enterprise: structuring and identification of elements]. Elektronne fakhove vydannja «Efektyvna ekonomika» [Online Professional Edition «Effective Economics»] (electronic journal), no. 7, pp. 1-15. Available at: http://www.economy.nayka.com.ua/?op=1\&z=1295 (accessed 12 September 2019). 
16. Voloshchuk L.O. (2015). Kontseptualni zasady upravlinnia ekonomichnobezpechnym innovatsiinym rozvytkom promyslovoho pidpryiemstva ta formuvannia yoho analitychnykh instrumentiv [Conceptual bases of management of economically safe innovative development of industrial enterprise and formation of its analytical tools]. Ekonomika: realii chasu [Economy: the realities of time]. (electronic journal), no. 1(17), pp. 234-241. Available at: http://economics.opu.ua/ files/archive/2015/No1/234-241.pdf (accessed 28 September 2019).

17. Filyppova S.V. (2013). Otsiniuvannia ekonomichnykh pokaznykiv diialnosti orhanizatsii na zasadakh vrakhuvannia pohliadiv hrup ekonomichnoho vplyvu [Assessment of economic performance of the organization on the basis of taking into account the views of groups of economic influence]. Ekonomika: realii chasu [Economy: the realities of time]. (electronic journal), no. 2(7), pp. 235-240. Available at: http://economics.opu.ua/files/archive/2013/n2.html accessed 30 September 2019).

18. Balatskyi O.F. (2006). Ekonomycheskyi potentsyal admynystratyvnikh y proyzvodstvennikh system: monohrafia [The economic potential of administrative and production systems: monograph]. Sumy: Unyversytetskaia knyha. (in Ukrainian)

19. Kalinesku T.V. (2007). Stratehichnyi potentsial pidpryiemstva: formuvannia ta rozvytok: monohrafiia [Strategic potential of the enterprise: formation and development: monograph]. Luhansk: Vyd-vo SNU im. V. Dalia. (in Ukrainian)

20. Rossokha V.V. (2009). Teoretyko-metodychni zasady formuvannia, rozvytku ta otsiniuvannia vyrobnychoho potentsialu silskohospodarskoho pidpryiemstva [Theoretical and methodological principles of formation, development and evaluation of production potential of agricultural enterprises]. Kiev: NNTs IAE. (in Ukrainian)

21. Hryshova Yu.I., Hatieva T.M. (2013). Pidkhody do formuvannia innovatsiinoho potentsialu pidpryiemstv kharchovoi promyslovosti [Approaches to formation of innovative potential of food industry enterprises]. Innovatsiina ekonomika, no. 1, pp. 15-18.

22. Dolzhanskyi I.S., Zahorna T.O., Udalykh O.O., Herasymenko I.M., Rashchupkina V.M. (2006). Upravlinia potentsialom pidpryiemstva [Enterprise potential management]. Kiev: Tsentr navchalnoi literatury. (in Ukrainian)

23. Kriukova I.O. (2007). Resursnyi potentsial ahrarnykh pidpryiemstv ta kompleks zakhodiv z yoho vidtvorennia i ratsionalnoho vykorystannia [Resource potential of agricultural enterprises and complex of measures for its reproduction and rational use]. Visnyk KhNAU. Seriia «Ekonomika APK i pryrodokorystuvannia», no. 3, pp. 97-97.

24. Berezi O.V., Plotnyk O.D. (2012). Ekonomichnyi potentsial ahrarnykh pidpryiemstv: mekhanizmy formuvannia ta rozvytku [Economic potential of agricultural enterprises: mechanisms of formation and development]. Poltava: Inter Hrafika. (in Ukrainian)

25. Mamonov K.A., Uhodnikov O.I. (2009). Ekonomichnyi potentsial: teoretychni aspekty ta liniia transformatsii [Economic potential: theoretical aspects and the line of transformation]. Visnyk ekonomiky transportu i promyslovosti, no. 26, pp. 198-202.

26. Kurochenko O.V., Kopnov M.A., Sladkevych V.P. and etc. (2008). Ekonomika: vid A do Ya: Poniatiino-terminol. Slovnyk [Economics: A to Z: Conceptual Terminol. vocabulary]. Kyiv: DP «Vydavnychyi dim «Personal». (in Ukrainian) 
27. KutsenkoA.V.(2008). Orhanizatsiino-ekonomichnyimekhanizm upravlinnia efektyvnistiu diialnosti pidpryiemstv spozhyvchoi kooperatsii Ukrainy: monohrafiia [Organizational and economic mechanism of management of efficiency of activity of the enterprises of consumer cooperation of Ukraine: monograph]. Poltava: RVV PUSKU. (in Ukrainian)

28. Kuznetsov B.L. (1999). Vvedenye $v$ ekonomycheskuiu synerhetyku [Introduction to economic synergetics]. Naberezhnye Chelnyi: KamPY. (in Russian)

29. Otenko Y.P. (2004). Metodolohycheskye osnovi upravlenyia potentsyalom predpryiatyia [Methodological bases of enterprise potential management]. Kharkov : Yzd-vo KhNEU. (in Ukrainian)

30. Savchenko M.V. (2004). Upravlinnia ekonomichnym potentsialom promyslovykh pidpryiemstv [Management of economic potential of industrial enterprises] (PhD), Kharkiv.

31. Fedonin O.S., Riepina I.M., Oleksiuk O.I. (2005). Potentsial pidpryiemstva: formuvannia ta otsinka: navch.-metod. posib. dlia samostiinoho vyvchennia dystsypliny [Enterprise potential: formation and assessment: training method. tool. for independent study of discipline]. Kyiv : KNEU. (in Ukrainian)

32. Zakon Ukrainy «Pro priorytetni napriamy innovatsiinoi diialnosti v Ukraini» [Priority directions of innovative activity in Ukraine] № 3715-VI vid 08.09.2011 r. (tlectronic resource) Available at: https://zakon.rada.gov.ua/laws/show/3715-17 (accessed 28 September 2019).

33. Akmaiev A.I., Kliianenko A.I., Osyka O.P. and etc. (2008). Ekonomika y orhanizatsiia innovatsiinoi diialnosti [Economics and organization of innovative activity]. Luhansk: IEPD NAN Ukrainy, SNU im. V. Dalia. (in Ukrainian)

34. Oviechkina O.A., Ivanova K.V. (2007). Ohliad metodiv otsinky rivnia innovatsiinoho potentsialu ekonomichnykh subiektiv [An overview of methods for assessing the level of innovation potential of economic entities]. Ekonomichnyi visnyk Donbasu, no. 4, pp. 130-140.

35. Sydorchuk I.P. (2014). Sutnist, struktura ta osoblyvosti otsiniuvannia innovatsiinoho potentsialu promyslovoho pidpryiemstva [The essence, structure and features of evaluating the innovation potential of an industrial enterprise]. Ekonomika $i$ rehion [Economy and region] (electronic journal), no. 2(45), pp. 97-101. Available at: http://jeou.donnu.edu.ua/article/view/1115/1134 (accessed 28 September 2019).

36. Filyppova S.V., Voloshchuk L.O., Smokvina H.A., Cherkasova S.O., Simakova N.M. (2009). Innovatsiina transformatsiia promyslovoho sektoru ekonomiky Ukrainy ta mekhanizmy yii rehuliuvannia [monograph] [Innovative transformation of the industrial sector of the Ukrainian economy and mechanisms for its regulation]. Odesa: «VMV». (in Ukrainian)

37. Stanislavyk O.V. (2007). Otsiniuvannia innovatsiinoho potentsialu promyslovykh pidpryiemstv Ukrainy: [monohrafia] [Assessment of innovation potential of Ukrainian industrial enterprises: [monograph]]. Odesa: TES. (in Ukrainian)

38. Voloshchuk L.O. (2015). Innovatsiinyi rozvytok ta ekonomichna bezpeka promyslovykh pidpryiemstv: problemy kompleksnoho upravlinnia: monohrafiia [Innovative development and economic security of industrial enterprises: problems of complex management: monograph]. Odesa: Bondarenko M.O. (in Ukrainian) 
39. Shylova O.Yu. (2012). Innovatsiinyi potentsial pidpryiemstva: sutnist ta mekhanizm upravlinnia [Enterprise innovation potential: essence and mechanism of management]. Marketynh i menedzhment innovatsii [Marketing and innovation management] (electronic journal), no. 1, pp. 220-227. Available at: http://mmi.fem.sumdu. edu.ua/sites/default/files/mmi2012_1_220_227.pdf (accessed 30 September 2019).

40. Krasnokutska N.V. (2003). Innovatsiinyi menedzhment: Navch. posibnyk [Innovation Management: Educ. Manual]. Kyev: KNEU. (in Ukrainian)

41. Vashchenko N. (2014). Sutnist innovatsiinoho potentsialu torhovelnoho pidpryiemstva [The essence of the innovation potential of a trading company]. Naukovyi visnyk Odeskoho natsionalnoho ekonomichnoho universytetu. Vseukrainska asotsiatsiia molodykh naukovtsiv [Scientific Bulletin of the Odessa National Economic University. All-Ukrainian Association of Young Scientists] (electronic journal), no. 1(209), pp. 5-17. Available at: http://dspace.oneu.edu.ua/jspui/bitstream/123456789/1181/3/ Науковий\%20вісник\%20№1.Pdf (accessed 01 October 2019).

42. Moroz O.S. (2012). Formuvannia systemy pokaznykiv dlia otsiniuvannia innovatsiinoho rozvytku pidpryiemstva [Formation of a system of indicators for evaluation of innovative development of the enterprise]. Ekonomyka Krima, no. 3(40), pp. 263-266.

43. Tymchenko O.I. (2012). Innovatsiina infrastruktura yak chynnyk zabezpechennia efektyvnosti innovatsiinoi diialnosti malykh pidpryiemstv [Innovative infrastructure as a factor in ensuring the efficiency of innovation activities of small businesses]. Efektyvna ekonomika [An efficient economy] (electronic journal), no. 12, pp. 1-6. Available at: http://www.economy.nayka.com.ua/ $\mathrm{op}=1 \& \mathrm{z}=1644$ (accessed 01 October 2019).

44. Voloshchuk L.O. (2014). Innovatsiinyi rozvytok promyslovoho pidpryiemstva: sutnist ta problemy analitychnoho zabezpechennia $\mathrm{v}$ umovakh indykatyvnoho upravlinnia [Innovative development of an industrial enterprise: the essence and problems of analytical support in terms of indicative management]. Biznes Inform [Business Inform] (electronic journal), no. 11, pp. 75-79. Available at: http://business-inform.net/export_pdf/business-inform-2014-11_0-pages-75_79.pdf (accessed 28 September 2019).

45. Nosovets O.I., Voloshchuk L.O. (2017). Problematyka zdiisnennia innovatsiinoi diialnosti vitchyznianymy ekonomichnymy subiektamy $\mathrm{v}$ umovakh chynnoho zakonodavstva [Problems of implementation of innovative activity by domestic economic entities in the conditions of the current legislation]. Biznes Inform [Business Inform] (electronic journal), no. 7, pp. 64-70. Available at: http://www.business-inform.net/ export_pdf/business-inform-2017-7_0-pages-64_70.pdf (accessed 01 October 2019).

46. Nosovets O.I., Voloshchük L.O., Kovtunenko K.V. (2018). Intellectual and innovative capital as an innovation activities results of industrial enterprises. Ekonomika: realii chasu [Economy: the realities of time]. (electronic journal), no. 4(38), pp. 49-60. Available at: https://economics.opu.ua/files/archive/2018/ No4/49.pdf (accessed 05 October 2019).

47. Voloshchuk L.O., Kirsanova V.V., Filyppova S.V. (2014). Analitychni instrumenty upravlinnia innovatsiinym rozvytkom promyslovoho pidpryiemstva : monohrafiia [Analyticaltoolsformanaging theinnovativedevelopmentofanindustrial enterprise: a monograph]. Odesa: Odes. nats. politekhn. un-t. (in Ukrainian) 